Article

\title{
Assessment of physicochemical, biochemical and functional properties of mucilage cocoa juice during storage at room tem- perature
}

\author{
Tano Marie-Ange Sakia Mian ${ }^{1,2}$, Fatoumata Camara ${ }^{2}$, Wahauwouele Hermann Coulibaly ${ }^{3, * 0}$, Grah Avit \\ Maxwell Beugré 1
}

How to cite this paper: Mian, T. M. A. S., Camara, F., Coulibaly, W. H., \& Beugré, G. A. M. (2022). Assessment of physicochemical, biochemi$\mathrm{cal}$ and functional properties of mucilage cocoa juice during storage at room temperature. Open Journal of Food and Nutrition, 1(1), 10-26. Retrieved from https://www.scipublications.com/journal/in-

dex.php/ojfn/article/view/186

Received: November 20, 2021

Accepted: February 3, 2022

Published: February 4, 2022

Copyright:@ 2022 by the authors. Submitted for possible open access publication under the terms and conditions of the Creative Commons Attribution (CC BY) license (http://creativecommons.org/licenses /by/4.0/).

\footnotetext{
${ }^{1}$ Laboratoire d'agro-valorisation; Unité de Formation et de Recherche d'Agroforesterie, Université Jean Lorougnon Guédé, Daloa, Côte d'Ivoire

${ }^{2}$ Laboratoire de Nutrition et Sécurité Alimentaire, Unité de Formation et de Recherche en Sciences et Technologie des Aliments (UFR-STA), Université Nangui Abrogoua, 02 BP 801 Abidjan 02, Côte d'Ivoire

${ }^{3}$ Laboratoire de Biotechnologie et Microbiologie des Aliments, Unité de Formation et de Recherche en Sciences et Technologie des Aliments (UFR-STA), Université Nangui Abrogoua, 02 BP 801 Abidjan 02, Côte d'Ivoire

*Correspondence: wahauwouele@yahoo.fr; +2250707731604; Côte d'Ivoire
}

\begin{abstract}
Beans cocoa exploitation process generated by-products such as mucilage cocoa juice This juice called "cocoa water" was often considered as waste because her storage is delicate at room temperature. The aim of this study was to assess self-life of mucilage cocoa juice during storage at room temperature. Consumption survey revealed that mucilage cocoa juice was selflife until 72 hours at room temperature and according to surveyed population, he possessed laxative, strengthening and anti-diarrheal properties. For all physicochemical, biochemical and functional parameters assessed during storage at room temperature, variations were irregulars. Also, mucilage cocoa juice samples have phenolic compounds contents and antioxidant activities important and high energetic values.
\end{abstract}

Keywords: Mucilage cocoa juice, storage at room temperature, phenolic compounds, antioxidant activities

\section{Introduction}

The cocoa tree (Theobroma cacao Linne) is widely farmed for its beans in tropical farms around the world [1]. Three nations (Côte d'Ivoire, Ghana, and Cameroun) are the largest producers, contributing for more than $70 \%$ of global production in 20182019. [2]. Only one country, Côte d'Ivoire, accounts for more than 35 percent of global production [2]. Her entire output was meant for sale to industrialized countries (Europe and America), where the fermented cocoa beans were mostly used to make chocolate. Cocoa "fermentation" is one of the phases in post-harvest processing that determines the quality of the final product. The cocoa beans are embedded in a mass of mucilaginous pulp in the pods, and after both beans and pulp were removed from the pods, the mucilaginous pulp was destroyed by pectinolytic enzymes to produce a mucilage fluid known as "cocoa water" or "cocoa honey" [3-4]. Mucilage juice is created when the mucilaginous pulp enclosing beans is broken down, resulting in cotyledon death [5]. This beverage is popular among farm laborers and their children. However, fermentation of cocoa beans involved multiple processes, resulting in by- 
products that are frequently discarded as waste. Indeed, each year, more than 300 million liters of mucilage liquid are wasted during the shucking process [6].

Furthermore, the high level of alcohol obtained after a few days of storage at room temperature in juice could indicate the presence of yeasts with a relatively high resistance and tolerance to alcohol and metabolites produced, such as organic acids (acetic acid, lactic acid, citric acid), and other products that influenced the taste [7]. Anvoh [6] found that under controlled fermentation to $28{ }^{\circ} \mathrm{C}$ and $35^{\circ} \mathrm{C}$, the alcohol concentrations of mucilage juice were $7.8 \%$ and $8.4 \%$, respectively, in her investigation.

According to Cocolin et al. [8], $38 \%$ and $54 \%$ of total isolates from cocoa bean fermentation could grow at 8,10 and $12 \%(\mathrm{v} / \mathrm{v})$ of ethanol, respectively. S. cerevisiae grew the fastest at $12 \%$ ethanol. The majority of investigations on cocoa fermentation were focused on beans at the time of handover. Some authors researched cocoa mucilage juice to transform it into marmalade, vinegar, wine, and refreshing beverages [4-6-7-9]. Therefore, objective of this study was to determine the maximum storage and consumption time of mucilage cocoa juice through survey. The physicochemical, biochemical and functional properties were investigated.

\section{Materials and Methods}

\subsection{Survey form}

A survey sheet has been prepared to determine the knowledge level of mucilage juice of cocoa, maximal storage time, beneficial effects eventual. The next analyses depended of survey results.

\subsection{Material}

The mucilage cocoa juices were collected from five (05) cocoa producers in different locations: Akoupé: $\left(6.3879^{\circ} \mathrm{N}, 3.8808^{\circ} \mathrm{W}\right)$ and Yakasse-Attobrou: $\left(6.1853^{\circ} \mathrm{N}\right.$, $\left.3.6446^{\circ} \mathrm{W}\right)$ in the south-east; Tiassalé $\left(5.9043^{\circ} \mathrm{N}, 4.8261^{\circ} \mathrm{W}\right)$ in the south; Taabo $\left(6.2338^{\circ} \mathrm{N}, 5.1394^{\circ} \mathrm{W}\right)$ in the center; and Buyo. Moreover, samples were taken from production equipment's, with five (05) liters being taken aseptically in sterile plastic bottles, the samples being maintained in a box containing ice, and being routed to the laboratory. The bottles were kept at room temperature in the laboratory. Each 24 hours, mucilage cocoa juices were sampled for different analyses.

\subsection{Methods}

\subsubsection{Study sites and population}

The surveys were conducted in the same localities where samplings have been carried. For this study, 500 people were interviewed with 100 per locality.

\subsubsection{Size of individuals to be investigated}

The sample size for this investigation was determined using Israel's [10] formula for a non-exhaustive independent sample.

$$
\mathrm{n}=\mathrm{t} 2(\mathrm{p}(1-\mathrm{p})) / \mathrm{e} 2
$$

With $\mathrm{n}$ denoting the sample size, e denoting the margin of error, $\mathrm{t}$ denoting the margin coefficient calculated from the confidence rate, and $\mathrm{p}$ denoting the population in the study area. Based on data from the general population census of Côte d'Ivoire, the sample for each area was created using the probability approach proportional to the size of households in each locale [11-12].

Consumers are given step-by-step instructions on how to complete the questionnaire on the websites. The questions were either multiple choice questions with two 
or three possible responses or yes/no questions with true/false answers. The final survey was organized around three (3) primary points: knowledge and consumption of cocoa mucilage juice, storage time of cocoa mucilage juice and eventual benefits effects of cocoa mucilage juice.

\subsubsection{Physicochemical and biochemical analyses}

The constant weight method was used to determine the ash content and moisture level [13]. Fat content was estimated using a Soxhlet extraction in according with method AOAC [13]. Protein content was evaluated with Kjeldahl method [13]. The amount of fibers in the sample was determined using Wolf's method [14]. The glucid total contents and energetic values were determined by calcul from others biochemical compounds contents.

The vitamins (ascorbic acid and cobalamin) organic acids (lactic, malic, oxalic, propionic, tartaric, citric and acetic acids) were separated and quantified by Shimadzu LC-6A Liquid Chromatograph, equipped by a detector (Shimadzu SPD-6A UV Spectrophotometric detector) a pump (Shimadzu LC-6A Liquid Chromatograph) and an Integrator (Shimadzu C-R 6A Chromatopac). An ion-exclusion ORH-801 column was used for chromatographic separation (300 $\mathrm{mm} \times 6.5 \mathrm{~mm}$, Interchrom, France). The eluant was $0.004 \mathrm{~N} \mathrm{H}_{2} \mathrm{SO}_{4}$ at a flow rate of $0.8 \mathrm{ml} / \mathrm{min}$, with a $210 \mathrm{~nm}$ detector. For HPLC samples, a $20 \mu \mathrm{L}$ injection volume was used. The analysis was carried out twice and the mean values were used. The organic acids standards were dissolved in distilled water at values between 0.05 and $0.4 \mathrm{~g} / \mathrm{L}$. The standards were filtered and injected into the same containers as the samples. By comparing retention periods and peak areas to those of a standard, components were found and quantified.

\subsubsection{Phytochemical contents of mucilage cocoa juice during storage at room tem- perature}

\subsubsection{Phenols total contents}

The Folin-Ciocalteu colorimetric technique was used to determine total phenol content [15]. After centrifugation, $250 \mu \mathrm{L}$ of diluted Folin-Ciocalteu-reagent $(10 \% \mathrm{v} / \mathrm{v})$ were added to a $50 \mu \mathrm{L}$ aliquot of the final result. After 1 minute, $750 \mu \mathrm{L}$ of aqueous $\mathrm{Na}_{2} \mathrm{CO}_{3}(20 \% \mathrm{w} / \mathrm{v})$ was added, and the volume was adjusted to $5.0 \mathrm{~mL}$ using $\mathrm{H}_{2} \mathrm{O}$. Except for the sample, the controls contained all of the reaction reagents. The absorbance was measured at $760 \mathrm{~nm}$ after 2 hours of incubation at $25^{\circ} \mathrm{C}$ and compared to both a gallic acid calibration curve and controls. Total phenols were measured in gallic acid equivalents per $\mathrm{mL}(\mathrm{g} G A E / \mathrm{mL})$, and the results were provided as the means of three measurements.

\subsubsection{Total flavonoid contents}

The $\mathrm{AlCl}_{3}$ colorimetric technique was used to estimate total flavonoid content [16]. A total of $0.5 \mathrm{~mL}$ of sample was mixed with the corresponding amounts of distilled water, aluminum trichloride $\left(\mathrm{AlCl}_{3}\right)$ 10\% (w/v) (Labosi, Paris, France), sodium acetate $(1 \mathrm{M})$, and $2 \mathrm{~mL}$ of water. On a Rayleigh spectrophotometer, absorbance at $415 \mathrm{~nm}$ was recorded after 30 minutes of incubation at room temperature (UV spectrophotometer; USA). Total flavonoid contents were determined using the means of three replicates and compared to a $0-300 \mathrm{~g} / \mathrm{mL}$ quercetin calibration curve (SigmaAldrich Chemie, Steinheim, Germany).

\subsubsection{Total tannins contents}

The Bate-Smith reaction, in which colorless proanthocyanidins are converted into colored anthocyanins by heating at $100{ }^{\circ} \mathrm{C}$ in an acidic solution and their amounts assessed based on their absorbance at $550 \mathrm{~nm}$, was used to determine easily 
extractable tannins [17]. Two (2 mL) sample, $1 \mathrm{~mL}$ distilled water, and $3 \mathrm{~mL} 12 \mathrm{~N}$ hydrochloric acid were added to two test tubes. One sample test tube was kept standing while the other was hermetically sealed and immersed in a water bath at $100{ }^{\circ} \mathrm{C}$ for 30 minutes before cooling in ice for 10 minutes. Each test tube received $0.5 \mathrm{~mL}$ of ethanol, and the optical densities were measured. The concentration of tannins in $\mathrm{g} / \mathrm{L}$ was determined by using the following equation, which is proportional to the concentration of anthocyanins.

$$
\text { Total tannins }=19.33 * \Delta D O
$$

The difference in optical density between the two tubes is denoted by $\Delta O D$

\subsection{Antioxidants activities}

\subsubsection{Antiradical activity: DPPH (2,2-diphenyl-1-picryl-hydrazyl) assay}

The DPPH assay method, which is one of the most widely used methods for assessing the antioxidant capacity of natural products, was chosen because of its simplicity and accuracy [18]. In the presence of an alcoholic solution of DPPH, yielding the free radical form DPPH, the antioxidant activities of mucilage cocoa juice are assessed by evaluating their respective free radical scavenging abilities [19]. In a methanol solution, the samples were mixed with the stable DPPH radical. $2 \mathrm{~mL}$ sample, 2 $\mathrm{mL}$ DPPH radical solution $100 \mathrm{mM}$ in methanol were added to the reaction mixture. When DPPH combines with an antioxidant that can donate hydrogen, it undergoes a transformation. From deep violet to bright yellow in color. Using a Rayleigh UV spectrophotometer, the color changes after 30 minutes of reaction time were measured as Absorbance (Abs) at $517 \mathrm{~nm}$ (USA). Using equation (3), the rate of scavenging activity (AA \%) was estimated as follows:

$$
A A=\left[\frac{X-Y}{X}\right] * 100
$$

Where $\mathrm{X}$ is the absorbance at $517 \mathrm{~nm}$ of oxidized DPPH in pure unreacted form and $\mathrm{Y}$ is the absorbance of the sample after 30 min incubation with DPPH.

\subsubsection{Ferric reducing-antioxidant power FRAP (potassium ferricyanide ferric chloride) assay}

Using the potassium ferricyanide-ferric chloride method, the ferric ion $\left(\mathrm{Fe}^{{ }^{+}}\right)$ reduction ability of mucilage cocoa juice samples was examined [20]. A $0.5 \mathrm{~mL}$ aliquot of each sample was mixed with $0.5 \mathrm{~mL}$ of phosphate buffer $(0.2 \mathrm{M}, \mathrm{pH} 6.6)$ and $0.5 \mathrm{~mL}$ of potassium ferricyanide $\mathrm{K}_{3} \mathrm{Fe}(\mathrm{CN})_{6}(1$ percent) and incubated at $50 \mathrm{C}$ for 20 minutes. A volume of $0.5 \mathrm{~mL}$ trichloroacetic acid $(10 \%(\mathrm{w} / \mathrm{v}))$ was used to stop the reaction. The absorbance of $0.5 \mathrm{~mL}$ of the reaction mixture was measured at $700 \mathrm{~nm}$ after it was mixed with $0.8 \mathrm{~mL}$ of distilled water and $0.1 \mathrm{~mL}$ of $\mathrm{FeCl}_{3}(0.1 \%)$. Each sample's reducing power was measured in $\mu \mathrm{g}$ of ascorbic acid equivalents (AAE) per $\mathrm{mL}$.

\subsection{Statistical analysis}

The R software was used to do an analysis of variance, and Tukey's test was used to identify differences between mean values $(P<0.05)$. In order to regroup mucilage cocoa juices during storage which have the same characteristics during storage, dendrogram was done using R. Pearson correlation analysis was used to look into any links between antioxidant activity and the presence of phenolic substances. 


\section{Results}

\subsection{Data survey}

\subsubsection{Profile of the surveyed population}

The survey allowed to establish socio-demographic profile of the respondents. The results showed that $79 \%$ of the respondents were male, compared with $31 \%$ who were female. The main age groups were 25 to 50 years $(62.2 \%)$ and 15 to 25 years (30.8\%). Most of the respondents had no education (54.4\%), the majority of whom worked in the agricultural sector $(71 \%)$, and married people $(67.8 \%)$ were the most numerous. Among the people interviewed, Ivorians (77.4\%) and Burkinabe $(19.8 \%)$ were the most dominant (Data not shown).

\subsubsection{Knowledge, consumption and frequency of consumption by the population} interviewed

The survey revealed that all respondents (500 people: $100 \%$ ) knew about mucilage cocoa juice and $98.8 \%$ of interviewed consumed it. Also, the respondents preferred to consume mucilage cocoa juice more during field work $(37 \%)$ and in the evening (33\%) with a frequency of 3 times $(31.80 \%)$ and more than 3 times $(32.60 \%)$ per day (Data not shown).

\subsubsection{Amount consumed, storage time and beneficial effect of mucilage cocoa} juice

Most interviewed claimed, that they consumed more than 3 liters per day $(52.8 \%)$ and that the cocoa mucilage juice had a maximum self-life of 3 days $(46.96 \%)$.

Number of respondents stated that they felt a beneficial effect (95.14\%) following the consumption of mucilage cocoa juice. Among these beneficial effects, the laxative (39.70\%) and strengthening (20.44\%) characteristics were the ones most mentioned by the interviewed (Table 1). 
Table 1. Amount consumed, storage time and beneficial effect of mucilage cocoa juice

\begin{tabular}{|c|c|c|}
\hline Parameters & $\begin{array}{c}\text { Number of re- } \\
\text { spondents }\end{array}$ & Percentage \\
\hline \multicolumn{3}{|c|}{ Amount of consumed juice $(n=494)$} \\
\hline $250 \mathrm{~mL}$ & 46 & 9.31 \\
\hline $500 \mathrm{~mL}$ & 98 & 19.89 \\
\hline $3 \mathrm{~L}$ & 261 & 52.80 \\
\hline Others & 89 & 18 \\
\hline \multicolumn{3}{|l|}{ Storage time $(n=494)$} \\
\hline 24 hours & 31 & 6.27 \\
\hline 48 hours & 145 & 29.37 \\
\hline 72 hours & 232 & 46.96 \\
\hline More than 3 times & 86 & 17.4 \\
\hline \multicolumn{3}{|l|}{ Benefit effect $(n=494)$} \\
\hline Yes & 470 & 95.14 \\
\hline No & 24 & 4.86 \\
\hline \multicolumn{3}{|l|}{ Effect $(n=494)$} \\
\hline Laxative & 196 & 39.70 \\
\hline Strengthening & 101 & 20.44 \\
\hline Anti-diarrheal & 80 & 16.19 \\
\hline Digest & 52 & 10.52 \\
\hline Others & 39 & 7.89 \\
\hline None & 26 & 5.26 \\
\hline
\end{tabular}

$\mathrm{n}=$ number of people surveyed

\subsection{Physicochemical and biochemical characteristics of mucilage cocoa juice during storage at room temperature}

From the survey's data, mucilage cocoa juice had a maximum self-life of 3 days. Thus, sampling during mucilage cocoa storage have been done until 3 days. The results of physicochemical and biochemical characteristics of mucilage cocoa juice during storage have been assessed each 24 hours during 72 hours ( 3 days).

\subsubsection{Evolution of physicochemical parameters of mucilage cocoa juice during storage at room temperature}

The analysis of physicochemical parameters was focused on dry matter, moisture, ash, protein, lipids, fibers and carbohydrate. The values of the evolution of these parameters were consigned in the Table 2. Generally, and whatever the parameter, the values of these parameters evolved in an irregular way during the conservation. On the other hand, total lipids and total fibers were not detected in our samples. From all the parameters studied, total carbohydrates have the highest content with more than $99 \%$. Furthermore, statistical analyses showed a significant difference between the samples during storage. 
Table 2. physicochemical parameters of mucilage cocoa juice during storage at room temperature

\begin{tabular}{cccccc}
\hline & & T0 & T24 & T48 & T72 \\
\hline & Dry matter & $12.29 \pm 0.063 \mathrm{a}$ & $12.31 \pm 0.084 \mathrm{a}$ & $11.89 \pm 0.014 \mathrm{a}$ & $5.29 \pm 0.14 \mathrm{c}$ \\
& Moisture & $87.70 \pm 0.063 \mathrm{e}$ & $87.64 \pm 0.014 \mathrm{c}$ & $88.11 \pm 0.014 \mathrm{e}$ & $94.725 \pm 0.16 \mathrm{c}$ \\
& Ash & $0.63 \pm 0.05 \mathrm{a}$ & $0.59 \pm 0.06 \mathrm{a}$ & $0.48 \pm 0.02 \mathrm{ab}$ & $0.38 \pm 0.04 \mathrm{~b}$ \\
& Protein & $0.30 \pm 0 \mathrm{~b}$ & $0.31 \pm 0.01 \mathrm{~b}$ & $0.77 \pm 0.01 \mathrm{a}$ & $0.37 \pm 0.01 \mathrm{~b}$ \\
& Lipid & 0 & 0 & 0 & 0 \\
Taabo & Fiber & 0 & 0 & 0 & 0 \\
& carbohydrate & $99.05 \pm 0.07 \mathrm{bc}$ & $99.08 \pm 0.1 \mathrm{a}$ & $98.73 \pm 0.04 \mathrm{~b}$ & $99.23 \pm 0.07 \mathrm{a}$ \\
\hline & Dry matter & $11.44 \pm 0.12 \mathrm{~b}$ & $6.965 \pm 0.02 \mathrm{~b}$ & $8.605 \pm 0.1 \mathrm{c}$ & $10.04 \pm 0.007 \mathrm{a}$ \\
& Moisture & $88.56 \pm 0.12 \mathrm{~d}$ & $93.035 \pm 0.02 \mathrm{~b}$ & $91.395 \pm 0.10 \mathrm{c}$ & $89.95 \pm 0.007 \mathrm{e}$ \\
& Ash & $0.44 \pm 0.007 \mathrm{~b}$ & $0.25 \pm 0.03 \mathrm{c}$ & $0.285 \pm 0.012 \mathrm{c}$ & $0.43 \pm 0.04 \mathrm{~b}$ \\
& Protein & $0.40 \pm 0.009 \mathrm{a}$ & $0.25 \pm 0.009 \mathrm{c}$ & $0.33 \pm 0.01 \mathrm{~b}$ & $0.41 \pm 0.02 \mathrm{~b}$
\end{tabular}

\begin{tabular}{cccccc} 
Attobrou & carbohydrate & $99.14 \pm 0.02 \mathrm{bc}$ & $99.48 \pm 0.04 \mathrm{a}$ & $99.37 \pm 0.13 \mathrm{a}$ & $99.15 \pm 0.07 \mathrm{a}$ \\
\hline & Dry matter & $5.46 \pm 0.11 \mathrm{e}$ & $4.125 \pm 0.007 \mathrm{c}$ & $9.415 \pm 0.07 \mathrm{~b}$ & $8.7 \pm 0.16 \mathrm{~b}$ \\
& Moisture & $94.54 \pm 0.11 \mathrm{a}$ & $97.375 \pm 2.12 \mathrm{a}$ & $90.58 \pm 0.077 \mathrm{~d}$ & $91.3 \pm 0.16 \mathrm{~d}$ \\
Ash & $0.17 \pm 0.03 \mathrm{c}$ & $0.14 \pm 0.04 \mathrm{c}$ & $0.44 \pm 0 \mathrm{bc}$ & $0.425 \pm 0.03 \mathrm{~b}$ \\
& Protein & $0.12 \pm 0.02 \mathrm{c}$ & $0.12 \pm 0.01 \mathrm{~d}$ & $0.30 \pm 0.009 \mathrm{~b}$ & $0.4 \pm 0.008 \mathrm{~b}$ \\
Lipid & 0 & 0 & 0 & 0 \\
Fiber & 0 & 0 & 0 & 0
\end{tabular}

\begin{tabular}{cccccc} 
Akoupé & carbohydrate & $99.69 \pm 0.06 \mathrm{a}$ & $99.73 \pm 0.05 \mathrm{a}$ & $99.27 \pm 0.04 \mathrm{a}$ & $99.17 \pm 0.04 \mathrm{a}$ \\
\hline & Dry matter & $5.875 \pm 0.02 \mathrm{~d}$ & $3.64 \pm 0.04 \mathrm{~d}$ & $3.545 \pm 0.007 \mathrm{~d}$ & $3.35 \pm 0.04 \mathrm{~d}$ \\
& Moisture & $94.125 \pm 0.02 \mathrm{~b}$ & $96.36 \pm 0.04 \mathrm{a}$ & $96.45 \pm 0.007 \mathrm{~b}$ & $96.65 \pm 0.04 \mathrm{~b}$ \\
Ash & $0.615 \pm 0.02 \mathrm{a}$ & $0.42 \pm 0.05 \mathrm{~b}$ & $0.62 \pm 0.03 \mathrm{a}$ & $0.63 \pm 0.07 \mathrm{a}$ \\
Protein & $0.3 \pm 0.008 \mathrm{~b}$ & $0.66 \pm 0.02 \mathrm{a}$ & $0.14 \pm 0 \mathrm{~d}$ & $0.2 \pm 0 \mathrm{c}$ \\
Lipid & 0 & 0 & 0 & 0 \\
Fiber & 0 & 0 & 0 & 0
\end{tabular}

\begin{tabular}{|c|c|c|c|c|c|}
\hline Tiassalé & carbohydrate & $98.74 \pm \mathrm{c}$ & $97,41 \pm a$ & $99,225 \pm a$ & $99,165 \pm \mathrm{a}$ \\
\hline & Dry matter & $7.28 \pm 0.02$ c & $3.075 \pm 0.007 \mathrm{e}$ & $2.675 \pm 0.16 \mathrm{e}$ & $2.445 \pm 0.03 \mathrm{e}$ \\
\hline & Moisture & $92.72 \pm 0.02 \mathrm{c}$ & $96.92 \pm 0.007 \mathrm{a}$ & $97.325 \pm 0.16 \mathrm{a}$ & $97.55 \pm 0.035 \mathrm{a}$ \\
\hline & Ash & $0.38 \pm 0.07 \mathrm{~b}$ & $0.27 \pm 0 \mathrm{c}$ & $0.40 \pm 0.04 \mathrm{bc}$ & $0.35 \pm 0.02 b$ \\
\hline & Protein & $0.27 \pm 0 \mathrm{~b}$ & $0.31 \pm 0 \mathrm{~b}$ & $0.25 \pm 0.01 \mathrm{c}$ & $0.46 \pm 0.01 \mathrm{a}$ \\
\hline & Lipid & 0 & 0 & 0 & 0 \\
\hline & Fiber & 0 & 0 & 0 & 0 \\
\hline
\end{tabular}

Buyo carbohydrate $99.32 \pm 0.42 \mathrm{ab}$

$99.41 \pm 2.2 \mathrm{a}$

$99.33 \pm 0.03$ a

$99.18 \pm 0.07$ a 
3.3 Evolution of biochemical parameters of mucilage cocoa juice during storage at room temperature

\subsubsection{Changes in the vitamin}

The analysis of vitamin content allowed identification and quantification of 2 vitamins: ascorbic acid and cobalamin. An irregularity in evolution of contents of vitamins (ascorbic acid and cobalamin) was observed for all samples (Table 3). Gobally, cobalamin contents were higher than ascorbic acid contents. The highest ascorbic acid and cobalamin contents were recorded at the beginning of storage in the Tiassalé sample with $14.97 \pm 0.45$ and $34.51 \pm 66.09 \mathrm{~g} / \mathrm{L}$ respectively. The lowest concentration of ascorbic acid was obtained with the Buyo sample after $48 \mathrm{~h}$ of conservation, while the lowest concentration of cobalamin was observed with the Akoupé sample at the beginning of conservation and the Buyo sample at the end of conservation with $10.245 \pm 0.5$ and $12.52 \pm 0.39 \mathrm{~g} / \mathrm{L}$ respectively. Furthermore, statistical analysis showed a significant difference between samples during storage.

Table 3. Vitamin contents $(\mathrm{g} / \mathrm{L})$ in mucilage cocoa juice during storage at room temperature

\begin{tabular}{cccccc}
\hline & & T0 & T24 & T48 & T72 \\
\hline Tiassalé & Ascorbic acid & $14.970 \pm 0.45 \mathrm{~b}$ & $2.465 \pm 0.02 \mathrm{e}$ & $3.59 \pm 0.57 \mathrm{fg}$ & $5.93 \pm 0.44 \mathrm{e}$ \\
\hline Yakassé & Cobalamin & $34.51 \pm 66.09 \mathrm{a}$ & $14.30 \pm 00 \mathrm{a}$ & $13.52 \pm 0.67 \mathrm{bc}$ & $14.87 \pm 0.7 \mathrm{a}$ \\
Attobrou & Ascorbic acid & $4.625 \pm 0 \mathrm{e}$ & $8.21 \pm 2.96 \mathrm{~d}$ & $7.74 \pm 1.65 \mathrm{de}$ & $4.545 \pm 1.12 \mathrm{e}$ \\
& Cobalamin & $14.665 \pm 0.38 \mathrm{bc}$ & $13.56 \pm 0.01 \mathrm{ab}$ & $12.87 \pm 1.06 \mathrm{c}$ & $12.52 \pm 0.39 \mathrm{abc}$ \\
\hline \multirow{2}{*}{ Buyo } & Ascorbic acid & $5.175 \pm 0.41 \mathrm{e}$ & $2.26 \pm 1.67 \mathrm{e}$ & $2.25 \pm 1.41 \mathrm{~g}$ & $5.255 \pm 0.64 \mathrm{e}$ \\
& Cobalamin & $13.84 \pm 0.81 \mathrm{bc}$ & $13.39 \pm 0.69 \mathrm{ab}$ & $15.935 \pm 2.43 \mathrm{~b}$ & $10.25 \pm 1.09 \mathrm{~cd}$ \\
\hline \multirow{2}{*}{ Akoupé } & Ascorbic acid & $10.435 \pm 0.86 \mathrm{~cd}$ & $7.5 \pm 0.7 \mathrm{~d}$ & $5.27 \pm 0.29 \mathrm{ef}$ & $9.205 \pm 2.89 \mathrm{~d}$ \\
& Cobalamin & $10.245 \pm 0.5 \mathrm{~cd}$ & $11.03 \pm 0.29 \mathrm{bc}$ & $20.61 \pm 0.25 \mathrm{a}$ & $12.15 \pm 0.19 \mathrm{bc}$ \\
\hline Taabo & Ascorbic acid & $7.43 \pm 0.43 \mathrm{de}$ & $9.6 \pm 0.63 \mathrm{~cd}$ & $9.29 \pm 0.12 \mathrm{~d}$ & $4.73 \pm 0.38 \mathrm{e}$ \\
\hline
\end{tabular}

Values are means \pm standard deviation, $n=3$. Means in the same column with different letters are significantly different according to Tukey's test $(p<0.05)$.

\subsubsection{Changes of the organic acid content}

The analysis of organic acid content by HPLC allowed identification and quantification of 6 organic acids: tannic, citric, tartaric, fumaric, lactic and acetic acids. As other parameters, evolution of organic acid contents during storage was irregular. The lowest concentration was obtained with fumaric acid, whatever sample, during the whole storage period, whereas highest concentrations were observed with citric and tartaric acids after 24 hours of storage in the Tiassalé sample, with $75.66 \pm 1.32$ and $77.77 \pm 1.31 \mathrm{~g} / \mathrm{L}$ respectively (Table 4 ). Furthermore, statistical analyses showed a significant difference between the samples during storage. 
Table 4. Organic acids content $(\mathrm{g} / \mathrm{L})$ of mucilage cocoa juice during storage at room temperature

\begin{tabular}{|c|c|c|c|c|c|}
\hline & & T0 & T24 & $\mathrm{T} 48$ & T72 \\
\hline \multirow{6}{*}{ Tiassalé } & Tannic acid & $0.505 \pm 0.02 \mathrm{ij}$ & $4.19 \pm 1.28 \mathrm{~h}$ & $2 \pm 0.021$ & $0.87 \pm 0.09 \mathrm{mn}$ \\
\hline & Acetic acid & $0.89 \pm 0.01$ hij & $7.42 \pm 0.04 \mathrm{fg}$ & $3.71 \pm 0.01 \mathrm{k}$ & $1.55 \pm 0.07 \mathrm{lmn}$ \\
\hline & Citric acid & $9.2 \pm 1.13 \mathrm{~cd}$ & $75.66 \pm 1.32 \mathrm{~b}$ & $35.68 \pm 0.1 \mathrm{c}$ & $15.83 \pm 1.37 \mathrm{e}$ \\
\hline & Lactic acid & $4.03 \pm 0.02 \mathrm{f}$ & $33.33 \pm 4.2 \mathrm{~d}$ & $17.53 \pm 1.3 \mathrm{e}$ & $6.97 \pm 0.09 \mathrm{i}$ \\
\hline & Fumaric acid & $0.062 \pm 0.001 \mathrm{j}$ & $0.51 \pm 0.01 \mathrm{kl}$ & $0.25 \pm 0.07 \mathrm{o}$ & $0.1 \pm 0.02 \mathrm{n}$ \\
\hline & Tartric acid & $9.45 \pm 0.07 \mathrm{~cd}$ & $77.77 \pm 1.31 \mathrm{a}$ & $36.8 \pm 0.07 \mathrm{ab}$ & $16.27 \pm 0.04 \mathrm{e}$ \\
\hline \multirow{6}{*}{$\begin{array}{l}\text { Yakassé } \\
\text { Attobrou }\end{array}$} & Tannic acid & $1.405 \pm 0.02$ ghij & $0.855 \pm 0.02 \mathrm{kl}$ & $0.99 \pm 0.007 \mathrm{mno}$ & $1.675 \pm 0.14 \mathrm{klmn}$ \\
\hline & Acetic acid & $2.57 \pm 0.09 \mathrm{fgh}$ & $1.66 \pm 0.29 \mathrm{jkl}$ & $1.8 \pm 0.07 \mathrm{~lm}$ & $2.55 \pm 0.11 \mathrm{klm}$ \\
\hline & Citric acid & $23.52 \pm 1.38 \mathrm{a}$ & $14.66 \pm 0.25 \mathrm{e}$ & $19.41 \pm 0.72 \mathrm{~d}$ & $21.44 \pm 1.14 \mathrm{~d}$ \\
\hline & Lactic acid & $10.55 \pm 1.34 \mathrm{c}$ & $6.71 \pm 0.37 \mathrm{~g}$ & $7.89 \pm 1.28 \mathrm{i}$ & $10.88 \pm 0.20 \mathrm{gh}$ \\
\hline & Fumaric acid & $0.16 \pm 0.007 \mathrm{j}$ & $0.1 \pm 0.00071$ & $0.13 \pm 0.02$ o & $0.18 \pm 0.004 \mathrm{n}$ \\
\hline & Tartric acid & $25.13 \pm 1.37 \mathrm{a}$ & $15.7 \pm 0.14 \mathrm{e}$ & $18.41 \pm 0.01 \mathrm{e}$ & $24.31 \pm 1.4 \mathrm{c}$ \\
\hline \multirow{6}{*}{ Buyo } & Tannic acid & $1.3 \pm 0.02 \mathrm{hij}$ & $1.98 \pm 0.02 \mathrm{ijk}$ & $1.9 \pm 0.01 \mathrm{~lm}$ & $1.57 \pm 0.04 \mathrm{lmn}$ \\
\hline & Acetic acid & $2.3 \pm 0.07$ fghi & $3.51 \pm 0.04$ hij & $3.63 \pm 0.04 \mathrm{k}$ & $2.82 \pm 0.05 \mathrm{kl}$ \\
\hline & Citric acid & $23.3 \pm 1.55 \mathrm{a}$ & $35.75 \pm 0.14 \mathrm{c}$ & $36.38 \pm 0.51 \mathrm{bc}$ & $28.25 \pm 1.59 \mathrm{ab}$ \\
\hline & Lactic acid & $10.34 \pm 0.07 \mathrm{c}$ & $15.78 \pm 0.02 \mathrm{e}$ & $16.24 \pm 0.01 \mathrm{f}$ & $12.49 \pm 1.28 \mathrm{fg}$ \\
\hline & Fumaric acid & $0.15 \pm 0.001 \mathrm{j}$ & $0.24 \pm 0.04 \mathrm{kl}$ & $0.21 \pm 0.04$ o & $0.19 \pm 0.003 n$ \\
\hline & Tartric acid & $24.095 \pm 2.87 \mathrm{a}$ & $36.43 \pm 0.57 c$ & $37.39 \pm 0.57 \mathrm{a}$ & $29.97 \pm 1.68 \mathrm{a}$ \\
\hline \multirow{6}{*}{ Akoupé } & Tannic acid & $0.41 \pm 0.02 \mathrm{ij}$ & $0.43 \pm 0.04 \mathrm{kl}$ & $0.8 \pm 0.04$ no & $0.58 \pm 0.01 \mathrm{n}$ \\
\hline & Acetic acid & $0.743 \pm 0.00$ hij & $0.752 \pm 0 \mathrm{kl}$ & $1.43 \pm 0.01 \mathrm{lmn}$ & $1.047 \pm 0.01 \mathrm{mn}$ \\
\hline & Citric acid & $7.58 \pm 2.71 \mathrm{de}$ & $7.6 \pm 0.42 \mathrm{fg}$ & $14.48 \pm 0.11 \mathrm{~g}$ & $10.47 \pm 2.72 \mathrm{~h}$ \\
\hline & Lactic acid & $3.33 \pm 1.37 \mathrm{fg}$ & $3.56 \pm 0.12 \mathrm{hi}$ & $6.39 \pm 0.12 \mathrm{j}$ & $4.61 \pm 0.15 \mathrm{j}$ \\
\hline & Fumaric acid & $0.05 \pm 0.003 \mathrm{j}$ & $0.054 \pm 0.0021$ & $0.097 \pm 0.009$ o & $0.07 \pm 0.01 \mathrm{n}$ \\
\hline & Tartric acid & $7.77 \pm 1.31 \mathrm{de}$ & $7.87 \pm 0.09 \mathrm{fg}$ & $14.88 \pm 1.3 \mathrm{~g}$ & $10.76 \pm 1.32 \mathrm{gh}$ \\
\hline \multirow{6}{*}{ Taabo } & Tannic acid & $0.80 \pm 0.03$ hij & $0.51 \pm 0.04 \mathrm{kl}$ & $0.56 \pm 0.01$ no & $1.57 \pm 0.09 \mathrm{lmn}$ \\
\hline & Acetic acid & $1.48 \pm 0.11$ ghij & $0.86 \pm 0.008 \mathrm{kl}$ & $0.976 \pm 0.008 \mathrm{mno}$ & $3.44 \pm 0.48 \mathrm{jk}$ \\
\hline & Citric acid & $14.48 \pm 0.11 \mathrm{~b}$ & $9.23 \pm 0.66 \mathrm{f}$ & $10.37 \pm 0.09 \mathrm{~h}$ & $27.915 \pm 0.75 b$ \\
\hline & Lactic acid & $6.92 \pm 0.65 \mathrm{e}$ & $4.32 \pm 0.73 \mathrm{~h}$ & $4.49 \pm 0.01 \mathrm{k}$ & $13.34 \pm 0.21 \mathrm{f}$ \\
\hline & Fumaric acid & $0.549 \pm 0 h i j$ & $0.058 \pm 0.0021$ & $1.03 \pm 0.01 \mathrm{mno}$ & $0.19 \pm 0.003 n$ \\
\hline & Tartric acid & $15.88 \pm 0.11 \mathrm{~b}$ & $8.97 \pm 0.09 \mathrm{f}$ & $9.92 \pm 0.02 \mathrm{~h}$ & $29.11 \pm 0.15 \mathrm{ab}$ \\
\hline
\end{tabular}

Values are means \pm standard deviation, $n=3$. Means in the same column with different letters are significantly different according to Tukey's test $(\mathrm{p}<0.05)$.

\subsubsection{Changes of the energetic value}

Changes of energetic value of the mucilage cocoa juices during storage was presented in Figure 1. It emerges from this analysis that these values were irregulars for all the samples. At the beginning of storage, the highest energetic value was obtained with Yakassé Attobrou sample with $363.05 \pm 0.13 \mathrm{Kcal} / 100 \mathrm{mg}$ DM followed by Tiassalé sample with $362.59 \pm 7.28 \mathrm{Kcal} / 100 \mathrm{mgDM}$ after 24 hours of storage. At 48 hours of storage, highest energetic value was recorded for Taabo sample with $369.53 \pm 0.57$ $\mathrm{Kcal} / 100 \mathrm{mgDM}$, whereas at the end of storage, this value was higher for Buyo sample $(364.38 \pm 0.17 \mathrm{Kcal} / 100 \mathrm{mg} \mathrm{DM})$. 


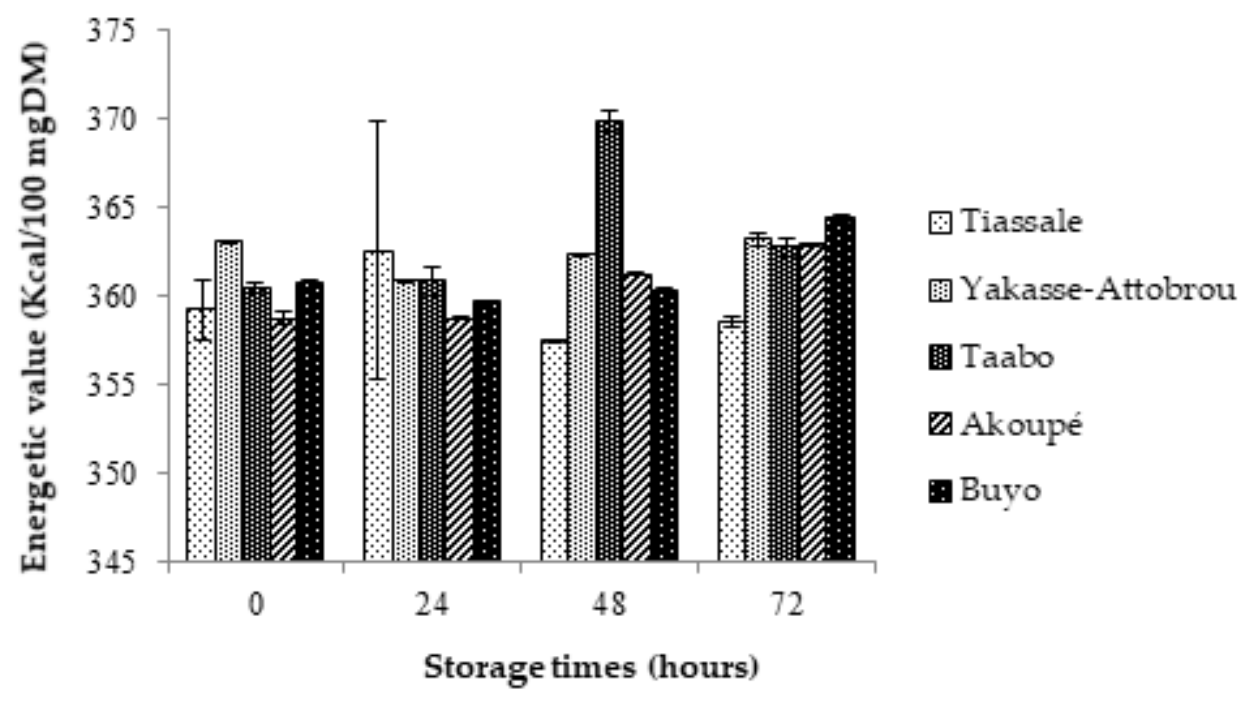

Figure 1. Evolution of energetic values of juices during storage

\subsection{Evolution of phytochemical compounds of mucilage cocoa juice during storage at room temperature}

\subsubsection{Changes of phenols total content}

Phenols total content of mucilage cocoa juice during storage was presented in Figure 2. These contents evolve irregularly during storage. However, whatever sample, highest levels of phenols total were observed in Tiassalé juices throughout storage period. These contents ranged from $1.17 \pm 0.7$ at the beginning of storage to $1.32 \pm 0$ $\mathrm{g} / \mathrm{L}$ GAE at the end of storage. Statistical analyses showed a significant difference between the samples during storage.

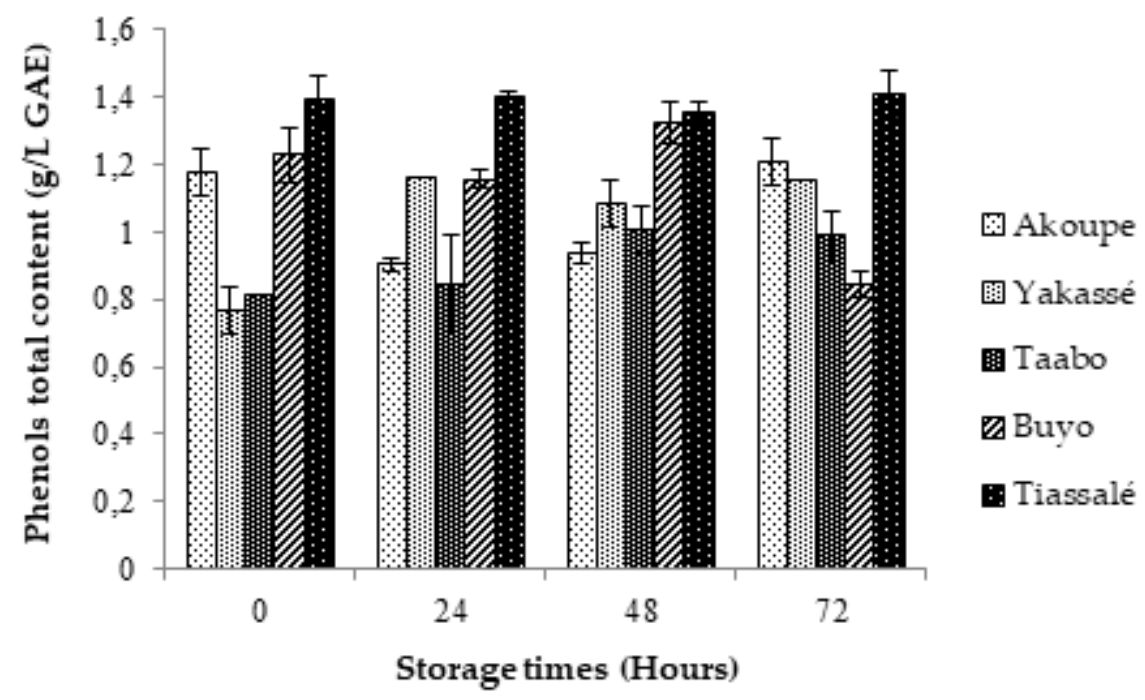

Figure 2. Phenols total contents variations of juices during storage

\subsubsection{Changes of flavonoids total content}

Figure 3 showed changes of total flavonoids contents of mucilage cocoa juice samples during storage. Like total phenols, total flavonoids evolution was characterized by irregular variations. Highest concentrations differed from one sample to 
another during storage. Thus, at the beginning of storage (0h), highest content was obtained with Akoupé sample with $0.083 \pm 0.00084 \mathrm{~g} / \mathrm{L} \mathrm{EQ}$, followed 24 hours later by Buyo sample with $0.14 \pm 0.00021 \mathrm{~g} / \mathrm{L}$ EQ, and then Yakasse-Attobrou sample at $48 \mathrm{~h}$ and at the end of storage (72h) with $0.21 \pm 0.00042$ and $0.16 \pm 0.001 \mathrm{~g} / \mathrm{L}$ EQ respectively. Also, the statistical analyses showed a significant difference between samples during storage.

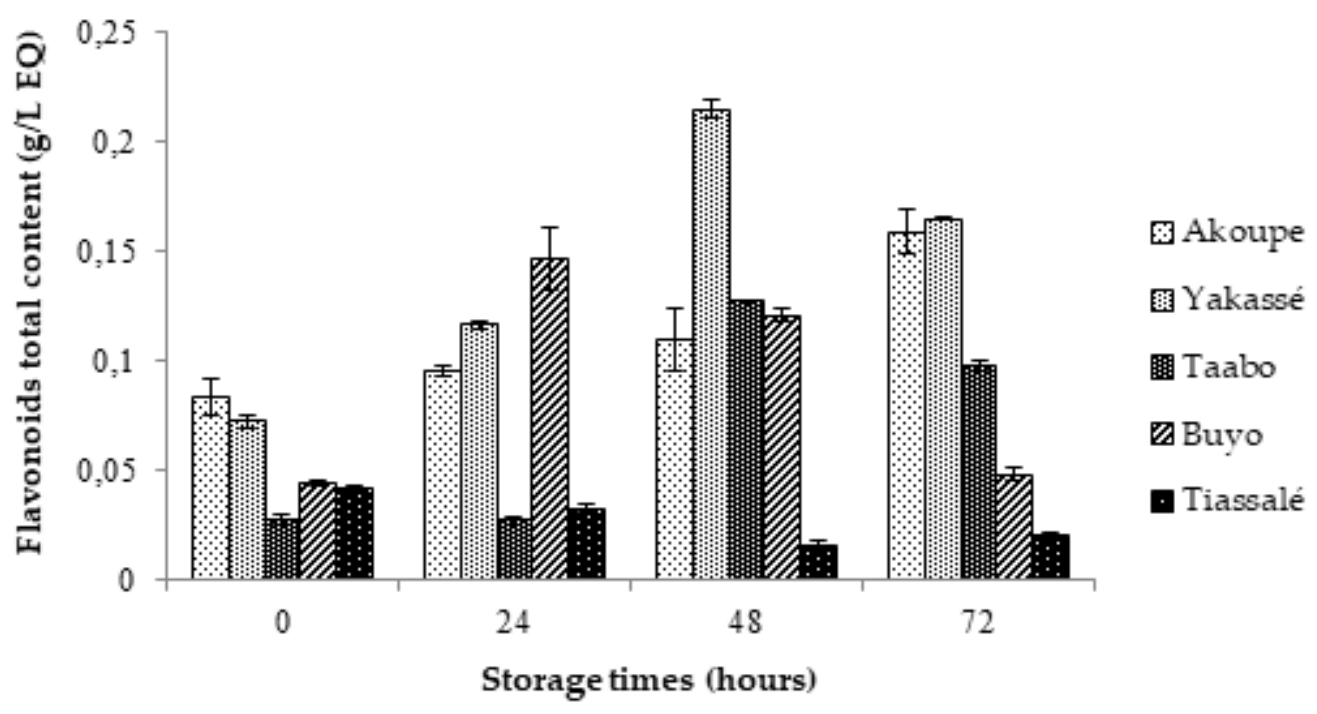

Figure 3. Flavonoids total contents variations of juices during storage

\subsubsection{Changes of tannins total content}

On the basis of total tannins content variations, samples can be classified into two groups. Thus, first group, was represented Akoupé and Tiassalé samples, which characterized by a decreasing in total tannins content during storage. The values went from $46.38 \pm 1.36$ to $2.89 \pm 0 \mathrm{~g} / \mathrm{L}$ and then from $60.40 \pm 0.68$ to $5.31 \pm 0.68 \mathrm{~g} / \mathrm{L}$ for Akoupé and Tiassalé samples respectively. The second group was composed of samples from Taabo, Yakasse-Attobrou and Buyo where total tannins content in mucilage cocoa juice during storage showed irregular fluctuations (Figure 4). Also, total tannins remained most abundant group of phenolic compounds in the juice samples. Furthermore, statistical analyses showed a significant difference between samples during storage.

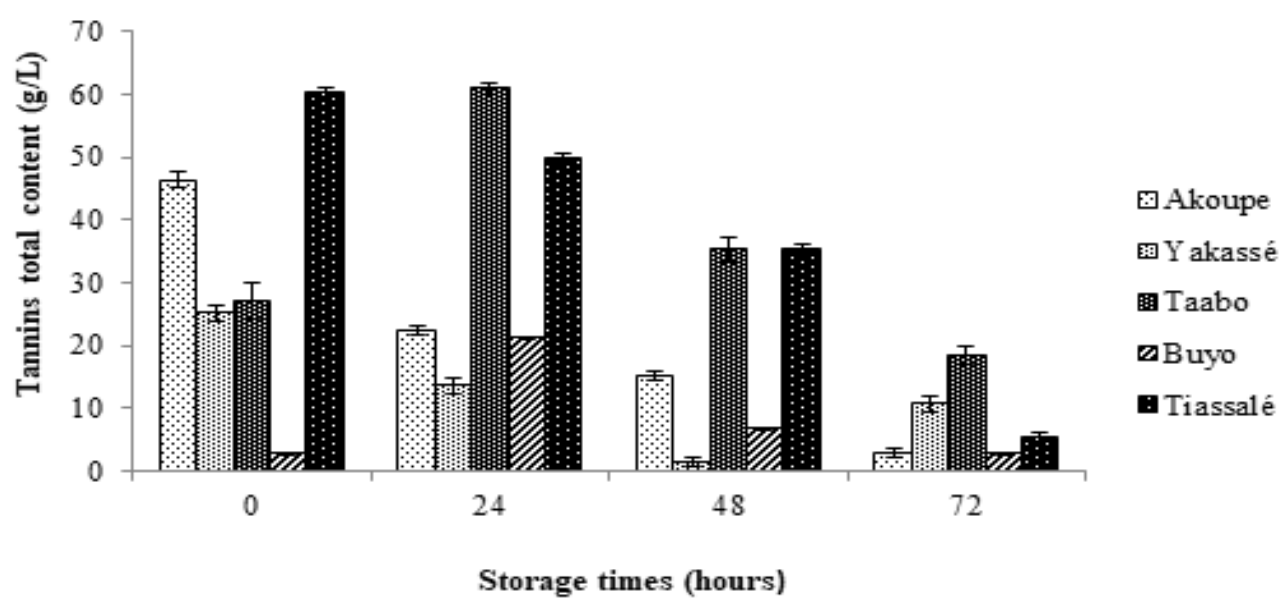

Figure 4. Tannins total contents variations of juices during storage 


\subsection{Antioxidant activities of mucilage cocoa juice during storage at room temperature}

\subsubsection{DPPH radical scavenging ability}

DPPH radical scavenging ability rate allowed to characterize samples according to their evolution. Thus, Akoupé and Taabo samples were by regular variations reflected by a decreasing in activity from $40.07 \pm 0.5$ to $7.63 \pm 0.01 \%$ and from $89.66 \pm 7.6$ to $2.35 \pm 0.01 \%$ respectively. The irregularities in evolution of antioxidant activity were observed in samples from Tiassalé, Yakasse-Attobrou and Buyo (Figure 5). In addition, a significant difference was recorded between the samples during storage.

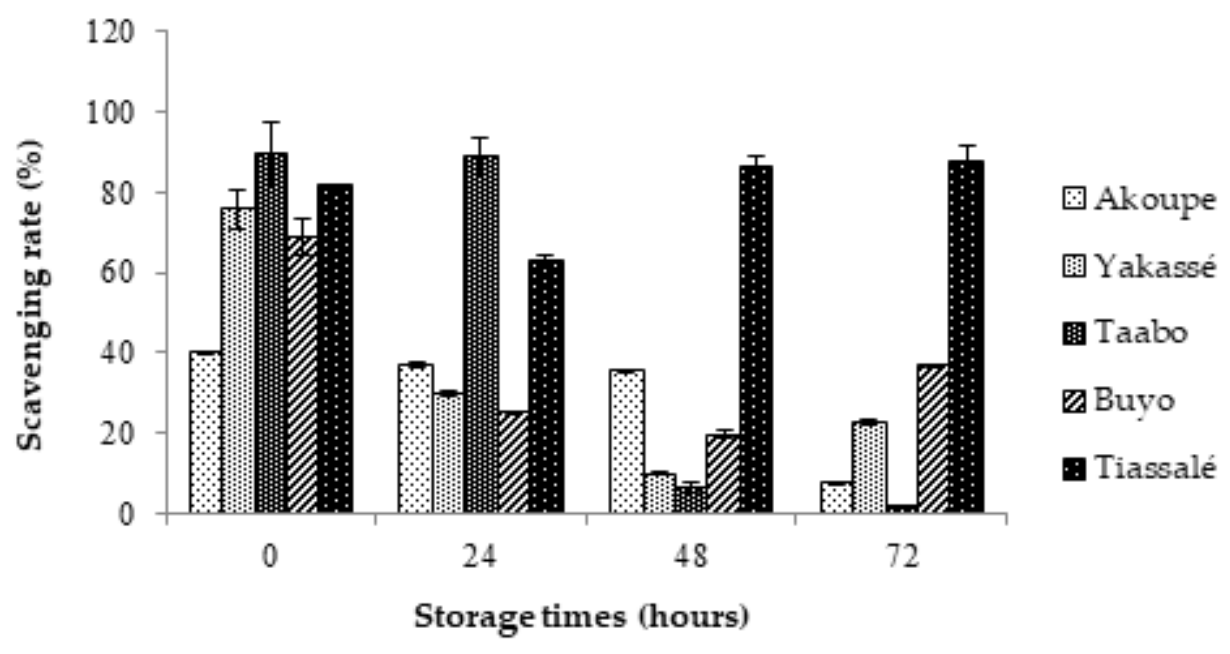

Figure 5. Scavenging rate of juices during storage

\subsubsection{Ferric reducing-antioxidant power FRAP (potassium ferricyanide ferric chloride)}

Evolution of antioxidant activity values determined by FRAP method was showed in Figure 6. For all samples, fluctuations were irregulars excepted for Taabo and Tiassalé samples. Taabo sample was characterized by an increase in antioxidant activity from $3.5 \pm 0.56 \mu \mathrm{g} / \mathrm{mL}$ of vitamin $\mathrm{C}$ at beginning of storage (0h) to $24.1 \pm 0.14$ $\mu \mathrm{g} / \mathrm{mL}$ of vitamin $\mathrm{C}$ at the end of storage (72h). On the other hand, in Tiassalé sample, a decrease in antioxidant activity was observed throughout storage period, with values lowed from $23.8 \pm 2.77$ to $7.43 \pm 0.9 \mu \mathrm{g} / \mathrm{mL}$ of vitamin C. Moreover, whatever sample, highest antioxidant activity was obtained with Buyo sample after $48 \mathrm{~h}$ of storage with $29.93 \pm 1.30 \mu \mathrm{g} / \mathrm{mL}$ of vitamin $C$ whereas lowest activity was recorded in Taabo sample at beginning of storage (0) with $3.5 \pm 0.56 \mu \mathrm{g} / \mathrm{mL}$ of vitamin C. Also, a significant difference was recorded between the samples during storage. 


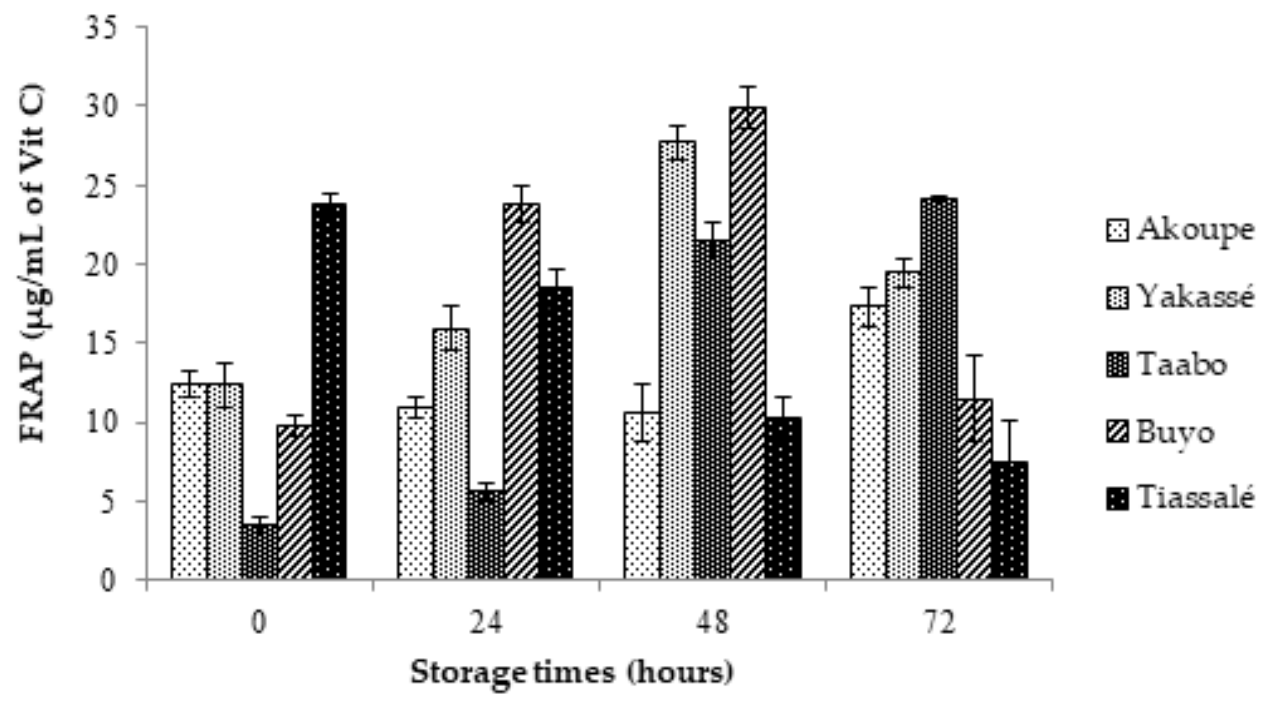

Figure 6. Antioxidant activity (FRAP) evolution of juices during storage

\subsection{Correlation between phenolic compounds and antioxidant activities of mucilage coco juice during storage at room temperature}

A correlation matrix has been created to explore the possible relationships between phenolic compounds and antioxidant activities during mucilage cocoa juice storage (tables not shown). At beginning storage (0h), antioxidant activity (FRAP) was positively correlated to total phenols and total tannins ( $r=0.698$ and $\mathrm{r}=0.688$ respectively). In contrast, a negative correlation has been observed between total flavonoids and antioxidant activity (DPPH) $(\mathrm{r}=-0.807)$. At 24 hours of storage, positive correlation has been recorded between antioxidant activity (FRAP) and total phenols and total flavonoids with $\mathrm{r}=0.761$ and $\mathrm{r}=0.610$ respectively whereas antioxidant activity (DPPH) and total tannins were positively correlated ( $r=0.967)$. Antioxidant activity (FRAP) was positively correlated with total flavonoids $(\mathrm{r}=0.678)$ and negatively with total phenols $(\mathrm{r}=-0.867)$, whereas correlation between antioxidant activity (DPPH) and total phenols was positive $(\mathrm{r}=0.545)$ and negative with total flavonoids $(r=-0.867)$ at 48 hours of storage.

At the end of storage (72h), the reducing power of ferric iron to ferrous iron (FRAP) was positively correlated with total flavonoids $(\mathrm{r}=0.705)$ and total tannins $(\mathrm{r}$ $=0.759)$. On the other hand, with free radical scavenging activity (DPPH), the analysis showed a positive correlation with total phenols with $\mathrm{r}=0.549$ and a negative correlation with total flavonoids where $\mathrm{r}=-0.732$.

\subsection{Cluster dendrogram of mucilage coco juices during storage at room temperature}

Dendrogram presented in Figure 7 revealed that during storage, mucilage cocoa juices sampled in 5 aeras where cocoa was cultivated, showed the similarities and differences. This analysis has been carried out on basis physicochemical, biochemistry, phytochemical compounds and antioxidant activities parameters data. In this paragraph correlation coefficients to axis not mentioned. Thus, at beginning of storage (0h), mucilage cocoa juices have been regrouped in 3 class: Akoupé and Tiassalé samples were similars; also, Yakasse-Attobrou and Buyo samples were similaries, but Taabo sample was different from previous samples (Figure 7a). At $24 \mathrm{~h}$ of storage, mucilage cocoa juice samples from Yakasse-Attobrou and Buyo were similars but different from others samples, which represented each one a different group (Figure $7 \mathrm{~b})$. After 48 hours of storage, cluster dendrogram showed that Akoupé and Yakasse- 
Attobrou samples consisted a same group which was different from others samples. For others samples, each one was different from one another (Figure $7 \mathrm{c}$ ). At the end of storage (72h), samples from Taabo and Yakassé-Attobrou were identical. The samples from Buyo, Tiassalé and Akoupé were different from each other (Figure 7d).

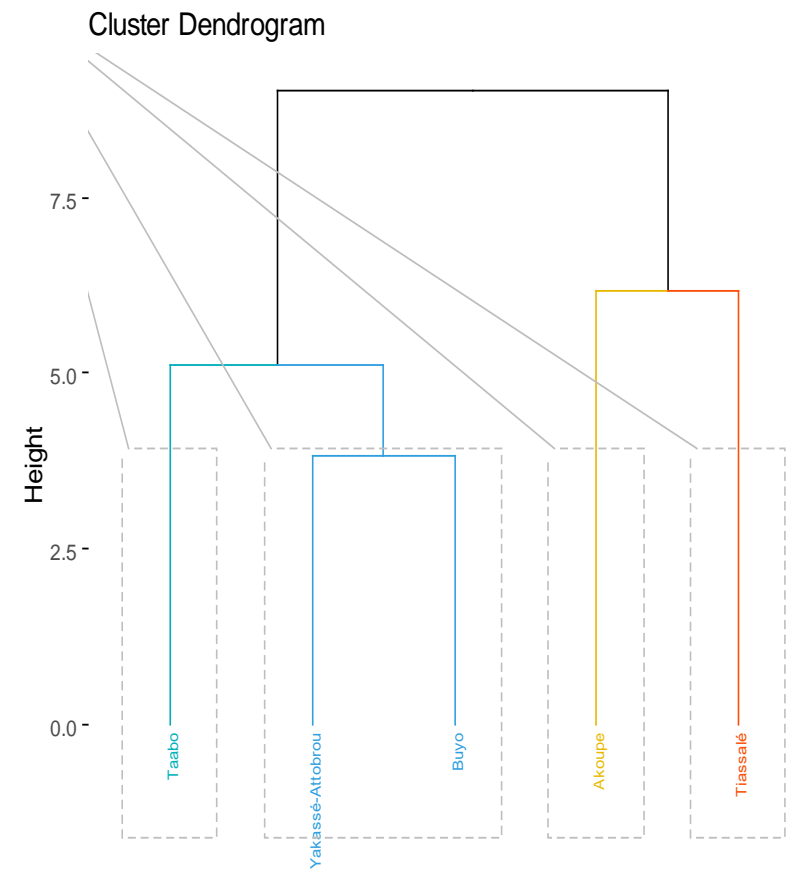

(a)

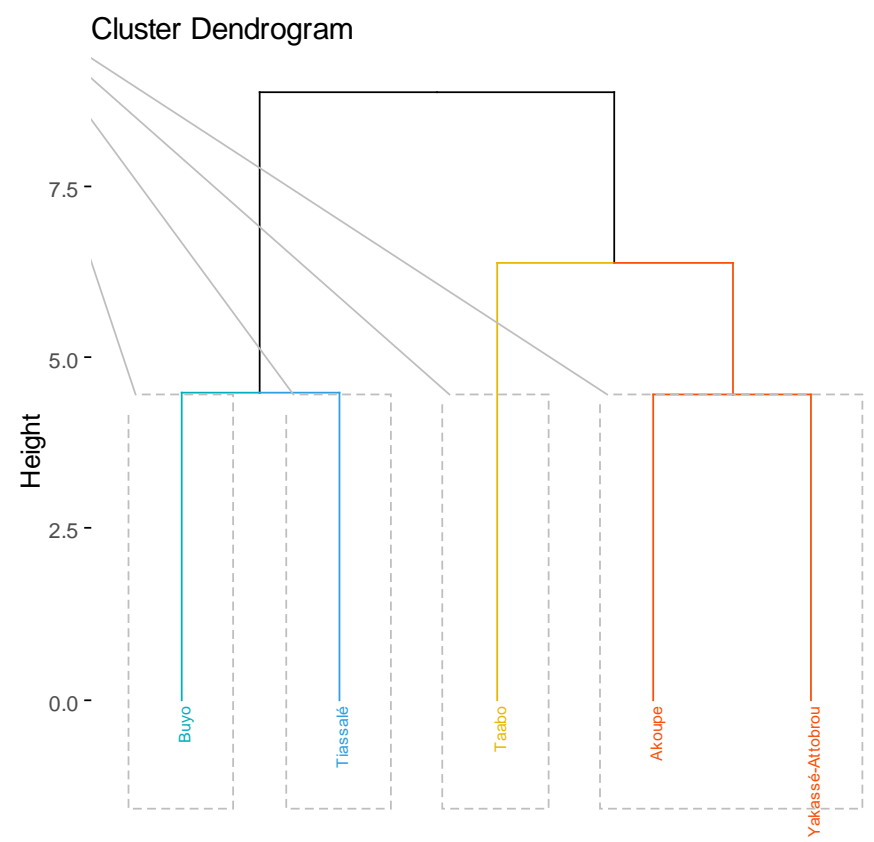

(c)

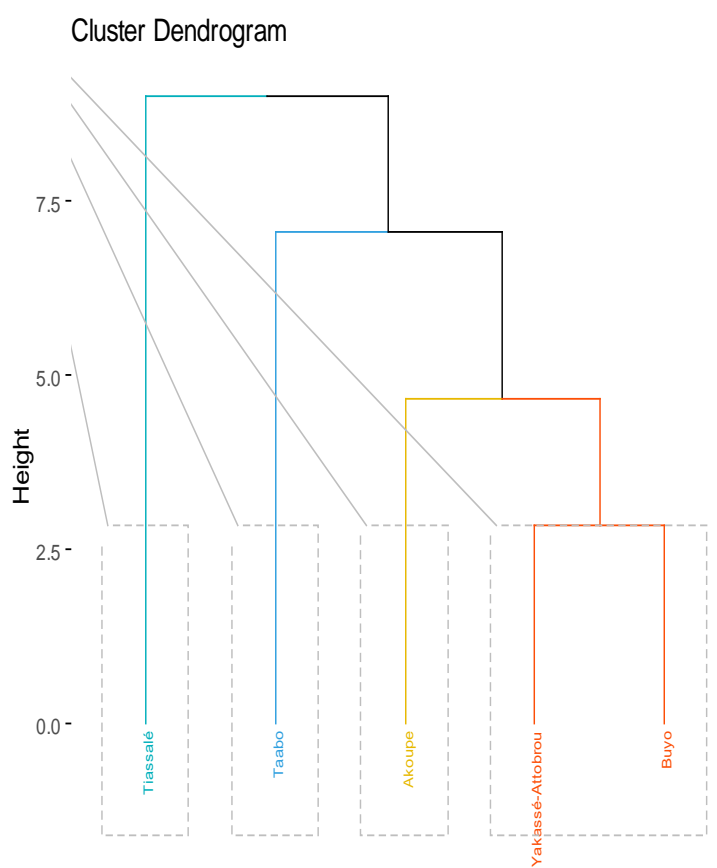

(b)

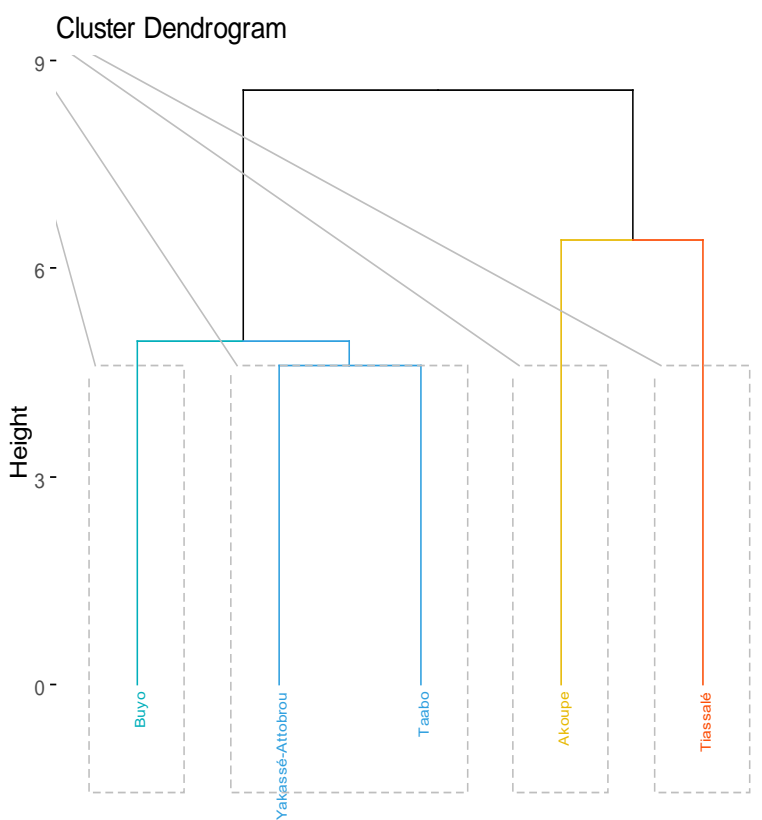

(d)

Figure 7. Cluster dendrogram of mucilage coco juices during storage at room temperature. (a) $0 \mathrm{~h}$ of storage; (b) $24 \mathrm{~h}$ of storage; (c) $48 \mathrm{~h}$ of storage; (d) $72 \mathrm{~h}$ of storage 


\section{Discussion}

Mucilage cocoa juice, a cocoa by-product generated during the beans processing, was derived from degradation of mucilaginous pulp coating beans by pectinolytic action of yeasts present in environment [21]. Thus, often considered as a waste product, mucilage cocoa juice could have interesting nutritional properties. A survey conducted to determine level of knowledge of mucilage cocoa juice by population, its maximum shelf-life and benefits attributed to it. The survey showed that mucilage cocoa juice was very well-known by population, especially in rural areas, and was consumed with great frequency. Also, its high frequency of consumption was linked to properties attributed by consumers, in particular laxative, strengthening and antidiarrheal. The maximum shelf-life of mucilage cocoa juice at room temperature storage was 3 days. In fact, people interviewed stated that juice was no longer pleasant to drink after 3 days because of alcohol produced. This alcohol occurrence associated with acidity of juice was due to spontaneous alcoholic fermentation triggered by yeasts present on beans processing equipment and in environment [22]. Thus, nutritional and functional analysis of mucilage cocoa juice during storage was carried out during 3 days.

Assessment of physicochemical, biochemical and functional parameters of mucilage cocoa juice showed in general an irregular evolution of these parameters. The moisture content values in this study were higher than those reported by Anvoh [6] and Werner et al. [7]. On the other hand, lipid, protein and ascorbic acid contents were higher in the samples of these authors than in this study but organic acids contents in this work were higher than values reported by Schwan; Ardhana and Fleet, [23-24] which were for citric acid, 2.1-2.4\% (w/w), lactic acid, $0.03 \%(w / w)$ and acetic acid, $0.04 \%(\mathrm{w} / \mathrm{w})$.

Moreover, vitamins such as ascorbic acid and cobalamin in juices of this study could give it strengthening property that consumers attribute to it.

Also, virtues of mucilage cocoa juice could be related to presence of phenolic compounds contents in the beans and the mucilage. Indeed, according to Lee et al [25], cocoa was very rich in polyphenols. Moreover, Bloch [26] pointed out that Ivorian cocoa was the third richest in phenolic compounds. Furthermore, Hanhineva, [27] reported that polyphenols were responsible of several properties.

Able to lower blood pressure in rats, prevent LDL (low density lipoprotein) oxidation, inhibit vascular smooth muscle cell proliferation, prevent platelet aggregation and stabilize immune cells.

They have been described as antioxidants, anti-platelet aggregation, anti-inflammatory, anti-allergenic, anti-thrombotic, neuroprotective, anti-viral, chemo-preventive and more evidence indicate that polyphenols influence lipid and carbohydrate metabolism [27].

Furthermore, fluctuations observed in phenolic compounds content and antioxidant activity, both assessed by DPPH and FRAP methods, could be due to cocoa variety, cultivation techniques or space. Niemenak et al. [28] claimed that polyphenol contents of cocoa during fermentation could increase by $25 \%$ for some varieties or decrease by $11-25 \%$ for other varieties. In this study, mucilage juices were obtained from several different varieties, hence the term "all types" in cocoa culture jargon. Also, these variations in phenolic compound levels and corresponding antioxidant activities could also be due to the cultivation techniques used, which vary from one region to another, and to environmental factors such as rainfall and temperature. Indeed, juices of this investigation were sampled from a part of the area called "the cocoa loop" which extends from the West to the East of Côte d'Ivoire through the Central region. In addition, the general analysis of mucilage cocoa juices from 5 
sample areas during storage showed that juices could present both similar and different characteristics during storage.

Dietary fiber as a compound contributing to digestion and production of soft stools would be responsible for the laxative character mentioned by consumers. However, analyses revealed only trace amounts of fiber, so laxative properties could be due to other compounds such as polyphenols. The latter have been reported as digestion-enhancing compounds [29-30]. Therefore, laxative property of mucilage cocoa juice would be more due to phenolic compounds than to dietary fiber. This same observation has been done par Coulibaly et al. [31] where phenolic compounds contents were most important in traditional sorghum beer than dietary fiber contents.

Also, irregular contents of physicochemical, nutritional and functional parameters would be largely related to microorganisms' activities, particularly fermentation, naturally present in juice. Koffi et al. [22] reported involvement of yeasts and moulds, acetic and lactic bacteria, Bacillus in the fermentation process of cocoa beans in Côte d'Ivoire. Thus, fluctuations observed in organic acids and phenolic compounds could be due to these microorganisms. Yeasts produce alcohol by transforming the sugars present in juice, such as acetic bacteria and lactic bacteria, which mainly produce acetic acid and lactic acid respectively. Furthermore, Macheix et al. [32] reported that yeasts were able to use phenolic compounds for their growth.

\section{Conclusion}

The survey on current state of knowledge of mucilage cocoa juice revealed that this juice was largely known by people. For these latter, maximal time of storage at room temperature was 72 hours and he possessed laxative, strengthening and antidiarrheal.

Physicochemical, biochemical and functional properties investigation of mucilage cocoa juice during storage at room temperature showed that irrespective of juice, variation of all parameters were irregulars. During storage at room temperature, juices exhibited differences and similarities. Also, juices have phenolic compounds contents and antioxidant activities important. For further investigation, storage parameters will be study for allow her consumption during long time.

\footnotetext{
Author Contributions: his work was carried out in collaboration between all authors. Authors FC and GAMB were responsible for study design and supervision of work. Authors WHC, and TMASM were responsible for laboratory work, data analysis and manuscript preparation. All authors read and approved the final manuscript

Funding: This research did not receive any specific grant from funding agencies in the public, commercial, or not-for-profit sectors.
}

Data Availability Statement: Data is not publicly available, only available by requesting email to corresponding author.

Acknowledgments: Participants of survey for their valuable time and support.

Conflicts of Interest: The authors declare no conflict of interest.

\section{References}

[1] Lopez A.S. and Dimick P.S. Cocoa fermentation In: Biotechnology (Reed, G. and Nagodawithana, T.W., Eds.), 2nd ed, Enzymes, Biomass, Food and Feed, Weinheim, Germany, 1995, 9, pp. 561-577.

[2] ICCO: International cocoa organization. The world cocoa economy, current status, challenges and prospects. Annual report (2019).

[3] Barel M. "Du cacao au chocolat, l'épopée d'une gourmandise." Quae. 2009. 
[4] Guirlanda C.P. da Silva G.G. Takahashi J.A. Cocoa honey: Agro-industrial waste or underutilized cocoa by-product? Future Foods, $2021 ; 4,100061$. https://doi.org/10.1016/j.fufo.2021.100061.

[5] Carr J.G. Cocoa. In: Rose, A.H. (Ed.), Fermented Foods: Economic Microbiology, 1982; 7. Academic Press, London, pp. 275-292.

[6] Anvoh K.Y.B. Caracterisation physico-chimique et microbiologique du jus de mucilage de la fève fraiche de cacao (Theobroma cacao L.) et sa transformation en produits dérivés : alcool, jus stabilise, marmelade, pate a tartiner, vinaigre. Thèse Unique, Abidjan, 27/10/2012.

[7] Werner B. Aliments et breuvages aromatiques à partir du cacao. Gate Information Service, gtz, $2000 ;$ pp. 18.

[8] Cocolin L. Visintin S. Alessandria V. Valente A. Dolci P. Molecular identification and physiological characterization of yeats, lactic acid bacteria, acetic acid bacteria isolated from heap and box cocoa beans fermentation in West Africa. International journal of food microbiology, 2016; 216, 69-78.

[9] Duarte FW. Dias D.R.Oliveira J.M. José A.Teixeira J.A. Silva J.B.A. Schwan R.F. Characterization of different fruit wines made from cacao, cupuassu, gabiroba, jaboticaba and umbu. LWT - Food Science and Technology, 2010; 43, 1564-1572. https://doi.org/10.1016/j.lwt.2010.03.010

[10] Israel D.G. Determining Sample Size. University of Florida. Fact Sheet PEOD-6, 5. Johnston, R.W., Tompkin, R.B., 1992. Meat and poultry products. In: Vanderzant, C., Splittstoesser, D.F. (Eds.), Compendium of Methods for the Microbiological Examination of Foods. American Public Health Association, Washington DC, 1992; pp. 821-835.

[11] Bartlett E.J.I. Kotrlik W.J. Higgins C.C. Organizational research: determining appropriate sample size in survey research. Inf. Technol. Learn. Perform. J. 2001; 19, 43-50.

[12] INS (Institut National de la Statistique) Recensement général de la population et des habitations, données socio-démographiques des localités. Région des Lagunes. Republique de Côte dIvoire. 1998; Tome I 83.

[13] AOAC., Offical methodes of analysis.AOAC Ed., Washington DC, 1990; pp 684.

[14] Wolf, Manuel danalyses des corps gras, 1968. Azoulay Ed., Paris, France, p. 519.

[15] Singleton V. Orthofer R. Lamuela-Ravento's R. Analysis of total phenols and other oxidation substrates and antioxidants by means of Folin-Ciocalteu reagent.In L. Packer (Ed.). Oxidants and antioxidants, part A, methods in enzymology, 1999; 299, pp. 152-178. New York: Academic Press

[16] Meda A. Lamien C.E. Romito M. Millogo J. Nacoulma O.G. Determination of total phenolic, flavonoid and proline contents in Burkina Faso honeys as well as their radical scavenging activity. Food Chemistry, 2005; 91, 571-577.

[17] Ribereau-Gayon P. and Stonestreet E. Dosage des tanins du vin rouge et détermination de leur structure. Chimie Anal, 1966; 48, 188-196.

[18] Alves C.Q. David J.M. David J.P. Bahia M.V. Aguiar RM. Metodos para determinaçao de atividade antioxidante in vitro em substratos org^anicos. Quím. Nova 2010; 33, 2202- 2210. https://doi.org/10.1590/S0100-40422010001000033.

[19] Brand-Williams W. Cuvelier M.E. Berset C. Use of free radical method to evaluate antioxidant activity. Lebensm. Wiss. Technol. 1995; 28, 25- 30. https://doi.org/10.1016/S0023-6438(95)80008-5.

[20] Liuk L. Sun Y. Laura T. Liang X. Ye H. Zeng X. Determination of polyphenolic content and antioxydant activity of Kudingcha made from Ilex kudingcha C.J. Tseng. Food chem. 2009;112, 35- 41.

[21] Barel M. De la cabosse à la tablette; Éditions Quae, 2013.

[22] Koffi B.L. Ouattara G.H. Karou T.G. Guehi S.T. Nemlin J.G. Diopoh J.K. Impacts de la fermentation du cacao sur la croissance de la flore microbienne et la qualité des fèves marchandes. Agronomie Africaine, 2013; 25(2), 159-170.

[23] Schwan R.F. Cocoa fermentations conducted with a defined microbial cocktail inoculum. Appl. Environ. Microbiol. 1998; 64, 1477-1483.

[24] Ardhana M.M. and Fleet G.H. The microbial ecology of cocoa bean fermentations in Indonesia. International Journal of Food Microbiology, 2003; 2732, 1-13.

[25] Lee K.W. Kim Y.J. Lee H.J. Lee C.Y. Cocoa has more phenolic phytochemicals and a higher antioxidant capacity than teas and red wine. J. Agric. Food Chem, 2003; 51, 7292-7295.

[26] Bloch S.A. Les polyohénols du cacao. 2014.

[27] Hanhineva K. Törrönen R. Bondia-Pons I. Pekkinen J. Kolehmainen M. Mykkänen H. Poutanen H. Impact of dietary polyphenols on carbohydrate metabolism. Int. J. Mol. Sci, 2010; 11, 1365-1402.

[28] Niemenak N. Rohsiusb C. Elwersb S. Ndoumou D.O. Liebere R. Comparative study of different cocoa (Theobroma cacao L.) clones in terms of their phenolics and anthocyanins contents. Journal of food composition and analysis, 2004; 19, 612-619.

[29] Gary W. Possible effects of dietary polyphenols on sugar absorption and digestion. Mol. Nutr. Food Res. $2013 ; 57,48-57$. https://doi.org/10.1002/mnfr.201200511.

[30] Tarko T. Duda-Chodak A. Zając N. Digestion and absorption of phenolic compounds assessed by in vitro simulation methods. Rocz. Panstw. Zakl. Hig. 2013; 64, 79-84.

[31] Coulibaly W. H. Bouatenin K. M. J-P. Cot M. Kouamé K. A. Tra Bi Y.C. Koky N. M.C. Djameh C. Djè K.M. Influence of yeasts on bioactive compounds content of traditional sorghum beer (tchapalo) produced in Côte d'Ivoire. Current research in food science, 2020; 3, 195-200. 
[32] Macheix J.J. Fleuriet A. Jay-Allemand C. Les composés phénoliques des végétaux: un exemple de métabolites secondaires d'importance économique. Presses polytechniques et universitaires romandes, 2005; p. 185 